\title{
CONSTRAINTS EXPERIENCED BY RICE FARMERS IN PRACTICING INDIGENOUS TRADITIONAL KNOWLEDGE PRACTICES (ITKs)
}

\author{
V. MEENAKSHI ${ }^{1} \&$ J. VENKATA PIRABU ${ }^{2}$ \\ ${ }^{1}$ Research Scholar, Department of Agricultural Extension and Rural Sociology \\ Tamil Nadu Agricultural University, Coimbatore, Tamil Nadu, India \\ ${ }^{2}$ Professor and Head Training Division, Directorate of Extension Education \\ Tamil Nadu Agricultural University, Coimbatore, Tamil Nadu, India
}

\begin{abstract}
A field survey was conducted in Thanjavur district of Tamil Nadu to identify the constraints faced by the rice farmers in practicing the ITKs. In this study primary data were collected through personal interview. The study specifically emphasizes the usefulness and constraints perceived by the rice farmers in practicing the ITKs. The data collection was done with the help of a well structured and pre tested interview schedule with a sample size of 240. Among the constraints, land constraints focused limited land available for farming was a dominating factor which determines the adoption of ITKs. Poor cattle possession experienced as one of the major constraints by a majority of the farmers. In case of irritation, non availability of water storage facility was a major constraint. Agriculture is facing a lot of issues on labour front and many practices transmitted by word of mouth rather than in written form were found to be the major constraints. The study also documented rice farmers' suggestions to overcome the constraints so as to conserve the ITKs for wider application in rice farming.
\end{abstract}

KEYWORDS: Indigenous Traditional Knowledge Practices (ITKs), Rice Farmers \& Constraints

Received: Sep 16, 2017; Accepted: Oct 06, 2017; Published: Oct 24, 2017; Paper Id.: IJESROCT201718

\section{INTRODUCTION}

Since, rice has many types of varieties, cultivation practices, soil types, and the management practices differ from place to place. This has provided ample scope for the use of ITKs evolved over generations. Farmers also encountered with various constraints at some point, in applying of ITKs.

According to Somasundaram (1995), indigenous knowledge is traditional knowledge, that is based on accumulated experience, much fitted to the local situation and social system. It is dynamic in nature (Ajani et al., 2013; Ayeri et al., 2012). People also use their knowledge and skills to assess risks from hazards, to plan and to execute actions that reduce risks through "anticipatory and proactive adaptation", in adopting ITKs. Tikai and Kama (2010), in their study of indigenous knowledge and its role to sustainable agriculture in Samoa, recommended proper recording and documentation of indigenous knowledge for agriculture and that, it is important to find who knows what, in order to tap the right source for data to truly reflect indigenous knowledge in the community, while documenting.

ITKs offer great opportunities for improved agricultural production and sustainable food security. Many authors have recognized it as an important source of development information (Anyira, 2010) and have 
recommended its proper documentation and dissemination, for sustainable agricultural development.

Okuneye and Ayinde (2004), Anyira (2010) cited that, small scale resource farmers have good reasons for sticking to their local knowledge and farming practices, because modern technologies can only be successful and sustainable, if indigenous knowledge is taken into consideration. One of the best and modern approaches to the preservation of traditional knowledge is documentation, in any permanent form and public accessibility. In addition to preservation, documentation and dissemination of agricultural indigenous practices provide an effective tool, for research and innovation.

\section{RESEARCH METHODOLOGY}

Thanjavur district is one of the indigenous traditional knowledge, practices intense district in rice farming and was chosen for the study.

\section{Selection of Respondents}

In Thanjavur district, the villages from each of the nine taluks were selected purposively, based on the intense ITK practices in rice cultivation. For the selection of villages, an inventory of revenue villages in each of the nine taluks was prepared. A total of 12 revenue villages were selected finally. A sample of 20 rice farmers (the respondents) was selected from each of the revenue villages, by adopting the simple random sampling method. A sample size of 240 was fixed for the study.

The data collection was done with the help of a well structured and pre tested interview schedule. The farmers were interviewed to list out their constraints, faced during the adoption of ITKs. They were also asked to give suggestions to overcome the constraints.

\section{RESULTS AND DISCUSSIONS}

\section{Constraints}

The constraints faced by the rice farmers while practicing ITKs were gathered under five dimensions viz.,

- Land constraints (limited availability of land for farming and high cost of farmland),

- Poor cattle possession (few cows or sheep or goat or pigs available, no separate Pastoral land, afraid of cattle disease and non availability of labour for cattle maintenance),

- Irrigation constraints (non availability of water storage facility, high cost of efficient irrigation systems, high cost of water management infrastructure and poor supply of electricity),

- iv) Labour constraints (non-availability of farm labour and labour wage rate is high (Minimum working hours per day),

- Other constraints (natural enemies of rice pests reduced -like birds due to radiation, trees) which was used as Green leaf manure become endangered species and some even destroyed, mode of transmission-many practices transmitted by word of mouth, rather than in written form, does not maximize profit suddenly.

The results have been presented in Table 1 and Figure. 1. 
Table 1: Distribution of Respondents According to their Constraints on Adoption of ITKs $(\mathbf{n}=\mathbf{2 4 0}) *$

\begin{tabular}{|c|c|c|}
\hline S. No & Constraints & Number \\
\hline $\mathbf{I}$ & Land Constraints & \\
\hline 1. & Limited availability of land for farming & 113 \\
\hline 2. & High cost of farm land & 98 \\
\hline II & Poor Cattle Possession & \\
\hline 1. & Few cows or sheep or goat or pigs available & 182 \\
\hline 2. & No separate Pastoral land & 219 \\
\hline 3. & Afraid of cattle disease & 135 \\
\hline 4. & Non availability of labour for cattle maintenance & 209 \\
\hline III & Irrigation & \\
\hline 1. & Non availability of water storage facility & 187 \\
\hline 2. & High cost of efficient irrigation systems & 123 \\
\hline 3. & High cost of water management infrastructure & 83 \\
\hline 4. & Poor supply of electricity & 60 \\
\hline VI & Labour Constraints & \\
\hline 1. & Non-availability of farm labour & 219 \\
\hline 2. & Labour wage rate is high & 212 \\
\hline 3. & Minimum working hours per day & 206 \\
\hline $\mathbf{V}$ & Other Constraints & \\
\hline 1. & Natural enemies of rice pests reduced (like birds due to radiation) & 196 \\
\hline 2. & $\begin{array}{l}\text { Trees which was used as Green leaf manure become endangered species and some even } \\
\text { destroyed }\end{array}$ & 162 \\
\hline 3. & $\begin{array}{l}\text { Mode of transmission (many practices transmitted by word of mouth rather than in written } \\
\text { form) }\end{array}$ & 120 \\
\hline 4. & Does not maximize profit suddenly & 191 \\
\hline
\end{tabular}

*-Multiple responses

It could be seen from the table1 that, among land constraints, limited availability of land for farming among farmers $(47.08 \%$ ) was a dominating factor, which determines the adoption of ITKs, followed by the high cost of farmland $(40.84 \%)$. Poor cattle possession experienced as one of the major constraints by a majority of the farmers. The animal possession angle revealed that no separate pastoral land $(91.25 \%)$, non availability of labor for cattle maintenance (87.08 $\%$ ), where the major constraint to adopt ITKs. The other major constraints include few cows or sheep or goat or pigs available (75.84 \%) and afraid of cattle disease (56.25\%). 
(A)

(C)

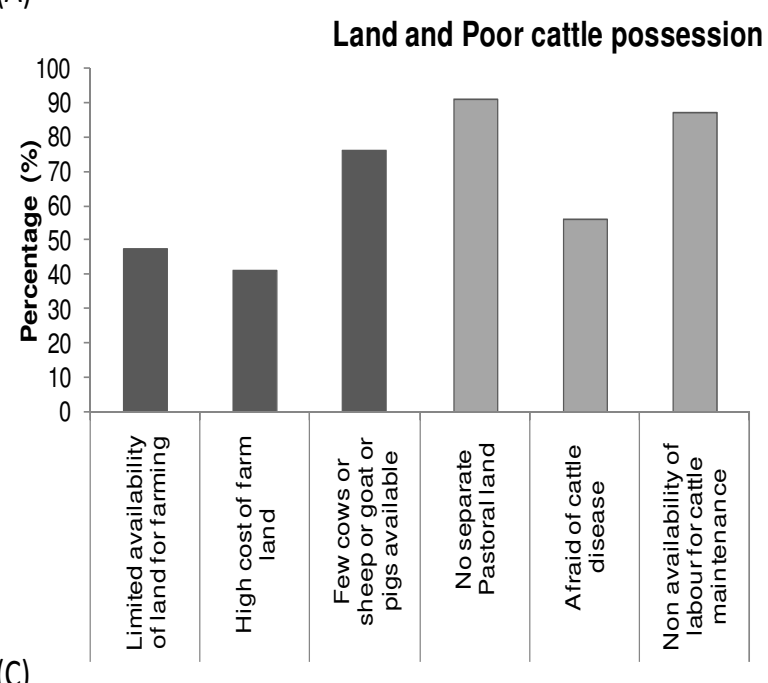

(B)

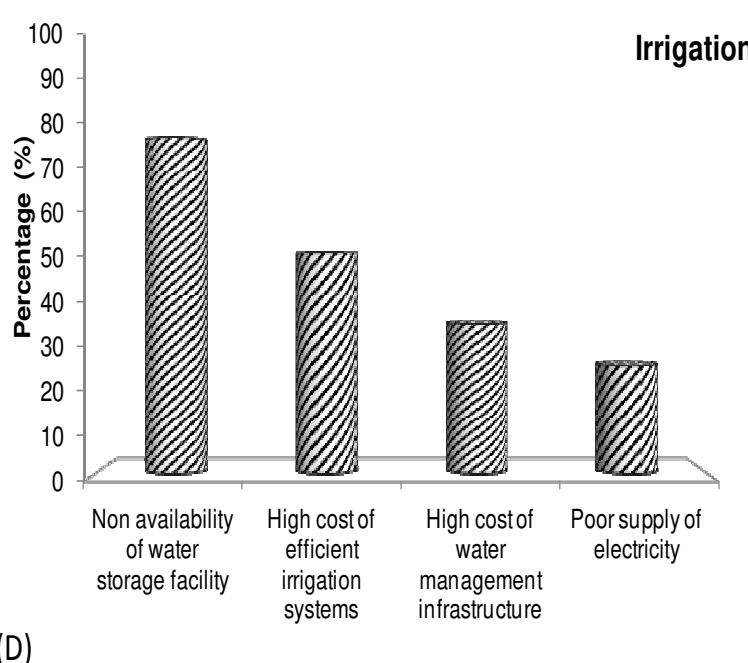

(D)

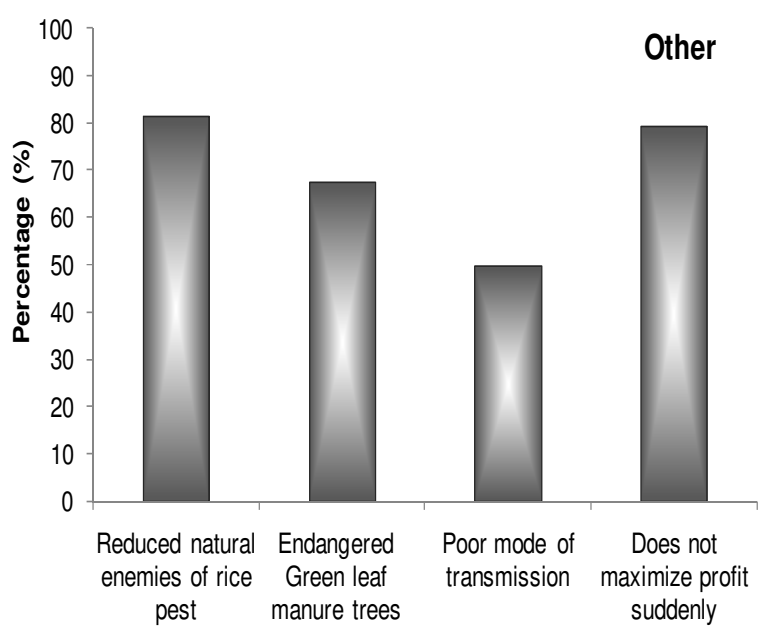

Figure 1: Percentage Wise Distribution of Respondents According to their Constraints (A) Labour and Poor Cattle Possession, (B) Irrigation, (C) labor and

(D) Other Constraints on Adoption of ITKs $(n=240)$

In case of irritation, non availability of water storage facility (77.92 \%), high cost of efficient irrigation systems $(51.25 \%)$, high cost of water management infrastructure (34.58 \%) and poor supply of electricity (25.00\%) were the major constraints. Agriculture is facing a lot of issues on the labour front. This was reported as major constraints, which prevent farmers from adopting ITKs in rice farming are as follows; non-availability of farm labour (91.25\%), the labour wage rate is higher $(88.33 \%)$, minimum working hours per day $(85.83 \%)$.

The other constraints which farmers have least, say are grouped under other constraints. It was found that, reduction in natural enemies of rice pest $(81.67 \%)$, does not maximize profit suddenly $(79.58 \%)$; trees which were used as green leaf manure become endangered species and some are even destroyed (67.5\%) and mode of transmission (many practices is transmitted by word of mouth, rather than in written form (50.00\%) were found to be the major constraints.

\section{Suggestions}

The respondents were further enquired to offer suggestions for effective functioning. The following were the suggestions emerged during the investigation. 
- Raise awareness about the value of ITKs through, record and share ITK success stories in folk songs, drawings, Puppet shows, storytelling, dramas, videos and other means of communication.

- Encourage, spread and educate on ITKs the local way and use

- To help communities conserve their ITKS by demonstrating the usefulness (handicraft enterprises, herbal gardens and organic farms)

- Help community member's record and their local practices (circulate identified rational ITK practices through books/ videos). Encourage the practice of record keeping.

- Make ITKs available (involve local people in preserving their ITKs, e.g. Farmers-managed local rice varieties bank)

- New documenting technique and standardizing techniques are encouraged.

- Promote revival of traditions and selected local practices (encourage the re-introduction of indigenous education. Encourage strengthening and establishment of indigenous organizations)

- Blending indigenous traditional knowledge with modern practices.

- Applying improved ITK practices. The improved ITKs can be promoted and applied through the extension service, farmer-centered extension, and other communication and education approaches.

- Other approaches for encouraging ITKs like farmers group discussion, brainstorming (can produce a quick overview or rough assessment of ITKs on a specific subject) and participatory approaches could be practiced.

- Participatory approaches to technology development have the advantage that local people have been involved in the development and testing of the improved 1TKs. They are therefore more likely to use and promote it successfully.

- Conducting village workshops, the reflection process helps people to understand and analyze their ITKs. The output can be used to help promote or improve an indigenous practice.

- Help community members: 1) validate information, 2) evaluates information and 3) recommend interventions.

\section{CONCLUSIONS}

An overview of the collected ITKs revealed that, many packages of practices recommended by change agents have been developed from indigenous practices. Among, land constraints, limited availability of land for farming was a dominating factor, which determines the adoption of ITKs. Poor cattle possession experienced as one of the major constraints by a majority of the farmers. In case of irritation, non availability of water storage facility was a major constraint. Agriculture is facing a lot of issues on labour front and many practices transmitted, by word of mouth rather than in written form were found to be the major constraints. These constraints may very well be overcome, by the suggestions. Hence, the extension agencies may try to include those ITKs in the technology dissemination process, in order to replace those modern technologies, which are hazardous to the environment and ecosystem. 


\section{REFERENCES}

1. Ajani, E. N., Mgbenka, R. N. and Okeke, M. N. 2013. Use of indigenous knowledge as a strategy for climate change adaptation among farmers in sub-saharan africa: Implications for policy. Asian Journal of Agricultural Extension, Economics and Sociology. africa.

2. Anyira, Isaac 2010. The role of libraries in the preservation and accessibility of indigenous knowledge in the Niger Delta Region of Nigeria. Library Philosophy and Practice. Available at http://www. faqs. org/periodicals/201006/2095013311. html (Accessed 22nd April, 2011).

3. Ayeri,O. S, Christian,V. R, Josef. E and Michael. H.2012. Local Perceptions and Responses to Climate Change and Variability: The Case of Laikipia District. Sustainability, 4: 3302-3325.

4. Okuneye P. A. and Ayinde, I. A. 2004. The relevance of local and indigenous knowledge for Nigerian agriculture. available: http://ma. caudillweb. com/documents/bridging/papers/adedipe. nimbe. pdf

5. Somasundaram, S. (1995). Indigenous Knowledge in Farming Systems. Un pub. Ph.D. (Ag.) Thesis, AC \& RI, TNAU, Coimbatore.

6. Tikai, P and Kama A.2010. A study of indigenous knowledge and its role to sustainable agriculture in Samoa. Ozean Journal of Social Sciences, Vol. 3, No.1. 